Studia Maritima, vol. XXXI (2018)

ISSN 0137-3587

DOI: $10.18276 / \mathrm{sm} .2018 .31-13$

Grażyna Szelągowska*

\title{
THE HISTORY OF SCANDINAVIA IN THE POLISH HISTORIOGRAPHY, REMARKS AND REFLECTIONS
}

Keywords: history of Nordic countries in Poland, Polish Scandinavian research workers, Polish historians.

\section{Summary}

The article outlines the achievements of the Polish historiography concerning the Nordic region, from the inter-war period to the present times. The problems dealt with are included in the two main trends of the Polish historical research concerning Scandinavian questions: the topics of Polish-Nordic relations of any kind, and the topics of the history of Scandinavia itself and of the Nordic region.

The third trend, much weaker than the two others, comprises the comparative studies concerning the social history, the history of states and cultures. Still another trend, the edition of sources to the history of the Nordic region, is hardly to be found in Polish historiography.

The article is also a review of the main centres of Scandinavian studies in Poland, both individual scholars, single historians functioning at departments of history at universities, and institutional centres of Polish Scandinavian Studies, especially the ones which carry out research into the whole region in an interdisciplinary approach: into languages, literature, culture, politics, economy and history. Some emphasis has been put on the weaknesses of the Polish research concerning the Nordic region, especially the ones resulting from the inability to use original archival materials and sources.

* dr hab. Grażyna Szelągowska prof. UW, Uniwersytet Warszawski, Instytut Historyczny, g.szelagowska@uw.edu.pl. ORCID: 0000-0002-4698-9518. 
At the beginning of the 1980s Maria Janion, an outstanding Polish scholar in the field of Romantic Literature, attracted the attention to the importance of the Scandinavian Middle Ages and the literature in Old Norse for Polish Romanticists, who in their artistic production drew heavily on the Nordic cultural stereotypes and the Medieval Scandinavian culture. ${ }^{1}$ In the ideology of Romanticism medievalism was important everywhere, but for the Polish artists - as Janion writes - it constituted 'the centre of all the times and a measure of history'. The Polish Romanticists kept learning Nordic languages; even more, they studied ancient texts in Old Norse, first of all sagas and the Elder (poetic) Edda.

But it was not a poet that was the first to translate the text of Elder Edda into Polish. The translation was done - not from Old Norse but on the basis of Latin and French texts - by Joachim Lelewel, the first Polish professional historian; in 1807 he published Edda or the Book of the Religion of Ancient Inhabitants of Scandinavia. The interest of Lelewel, as well as other Polish historians of the second half of the $19^{\text {th }}$ century, in the Nordic region was not accidental and did not result from the romantic spirit of the times. It was connected with the concepts of the genesis of the Polish people, who were linked to other peoples: the Scythians, the Goths, the Sarmatians and the Scandinavians themselves. In the mid- $19^{\text {th }}$ century it was Karol Szajnocha who might have come to the most extreme conclusion putting forward a theory of the so called Lechite state, according to which the first Polish state had been organised by a Scandinavian tribe of 'Lechites'. The present-day Polish Mediaevalists are still analysing the problem of the origin of Mieszko I: whether he was a stranger from the South (Moravia) or a Slav or a Viking from the North.

The above outlined problems fall into two main trends of Polish historical research into Scandinavia: the questions concerning Polish-Nordic relations in all spheres, and the history of Scandinavia and the Nordic region with hardly any references to Poland. The third trend, the least marked, is the edition of the sources for the research into the Nordic region. All these trends will be analysed from several points of view (which might lead to some repetitions) of what had been achieved by various historians in various research centres at various stages of research and in various subfields.

M. Janion, "Estetyka Średniowiecznej Północy”, in: Problemy polskiego romantyzmu. Series III, ed. M. Żmigrodzka (Wrocław: Ossolineum 1981). 
The most interesting achievements - in my opinion - of Polish historians in the field in question have been presented below; it is worth underlining that the remarks presented here do not exhaust the topic, and besides such was not the role of these randomly selected reflections. It should be emphasised that the article does not belong in the history of historiography, it is rather an essay, which does not exhaust the theme whatsoever. Several of its aspects, such as the analysis of journals and editorial series, although exceptionally important for the Polish Scandinavian studies, simply are beyond the scope of the article. Therefore, numerous petty studies published in academic journals have been hardly included here. The academic institutions, important from the point of view of their role as stimuli for research into the history of Scandinavia (e.g. the Baltic Institute in Gdańsk), and related to them editorial houses and series have been also passed over. Undoubtedly, they also deserve to be separately treated in several studies.

I'd rather attract the attention to the most interesting research areas, so far not fully explored by Polish scholars, as well as present reflections as for a further development of that section of Polish historiography. The present text should not be expected to include the bibliography of Polish academic publications concerning the Nordic region; instead, it is a subjective selection, so some names and titles might happen to be omitted. And so will be research centres affiliated to various institutes of political science and international relations (e.g. the Centre 'Norden', affiliated to the Warsaw University, or the Department of Nordic Countries, which is part of the Management and Administration Faculty of the Jan Kochanowski University in Kielce, and the like). It does not mean at all that the achievements of those centres are not appreciated, just the reverse, but - like in the case of journals and series - their activities deserve to be depicted more extensively than the preliminary reflections included in this article. In principle, the publications for general public are not mentioned, either; whereas, what does matter in research work is the participation of original sources and the equally original literature in Old Norse.

The preliminary remarks may be concluded with one reservation. These deliberations cannot be aimed at indicating detailed research themes and questions. Taking into account their size, it is the task of supervisors dealing with and seminars concerning the history and culture of Scandinavia.

Even the preliminary research indicates that the problems that prevail are the ones of the first trend: the Polish-Nordic relations of any kind, including the ones dealing with the pre-war period. There are two topics here: the one concerning 
diplomatic and military relations of the modern-age Poland with the Scandinavian countries (especially in the $17^{\text {th }}$ century), and the one concerning the political and diplomatic questions of the partition of Poland at the end of the $18^{\text {th }}$ century.

The attention should - first of all - be paid to the achievements of Władysław Konopczyński (1880-1952), one of the most outstanding Polish historians of the pre-war period, who as a research worker into the history of the Polish Commonwealth of the $18^{\text {th }}$ century attracted the attention to the Scandinavian questions, first of all to the diplomatic relations of the Commonwealth with Sweden and Denmark at the time of the partitions. His achievements in that sphere made him become a member of the Swedish Academy of Literature, History and Archaeology; the Scientific Society in Lund; and the Royal Society for Publishing Sources to the History of Scandinavia in Stockholm. Among his numerous works the ones that should be mentioned are: Polska a Szwecja ('Poland versus Sweden'); the two-volume Konfederacja Barska ('The Bar Confederation'), in which Konopczyński drew heavily on the diplomatic archival materials from Stockholm; Kwestia battycka do XX wieku (1947) ('The Baltic Question up to the $20^{\text {th }}$ Century'); and the posthumous edition of Pierwszy rozbiór Polski ('The First Partition of Poland'). ${ }^{2}$ Especially in the last work Konopczyński underlined the importance of the research conducted by Polish historians into the Polish partitions in the Swedish archives.

Władysław Czapliński, author of the only synthesis of the history of Denmark (this topic will be discussed later), paid much less attention to the Danish policy towards the Commonwealth at the time of partitions just mentioning that the Kościuszko Uprising had aroused the curiosity at the highest level in Denmark. ${ }^{3}$ Zbigniew Anusik, a present-day research worker of the Polish-Swedish relations at the time of Stanisław August(us) Poniatowski, treated the question of Denmark's attitude towards the Polish partitions in a similar way. ${ }^{4}$ However, it should be noted that the diplomatic sources of the Copenhagen State Archives (Rigsarkivet) and the Central Archives in Copenhagen (Elementa ad fontium

2 W. Konopczyński, Polska a Szwecja; od pokoju oliwskiego do upadku Rzeczypospolitej 1660-1795 (Toruń: Instytut Bałtycki 1935); W. Konopczyński, Konfederacja Barska, vol. 1-2 (Warsaw: Wydawnictwo Kasy im. Mianowskiego - Instytut Popierania Nauki, 1936-1938); W. Konopczyński, Kwestia bałtycka do XX wieku (Gdańsk: Baltic Institute, 1947); W. Konopczyński, Pierwszy rozbiór Polski (Cracow: Arcana, 2010).

3 W. Czapliński, K. Górski, Historia Danii (Wrocław-Warsaw-Cracow: Ossolineum 1965), 245.

4 Z. Anusik, Misja polska w Sztokholmie w latach 1789-1795 (Łódź: Wydawnictwo Uniwersytetu Łódzkiego 1993). 
editiones. Res Polonicae ex Archivo Regni Daniae) ${ }^{5}$ are the basis for the extensive five-volume publication of the correspondence and diplomatic documents of the $16^{\text {th }}-17^{\text {th }}$ centuries.

Among the Polish scholars of the pre-war period the one that should be mentioned is Oskar Halecki (1891-1973), a research worker of the history of the Polish-Lithuanian Union (Commonwealth). ${ }^{6}$ In his work Dzieje unii jagiellońskiej ('A History of the Jagiellonian Union') Halecki performs an interesting analysis, in which he compares the Scandinavian Kalmar Union to the Polish-Lithuanian Union of Krevo. Halecki's interest in the Jagiellonian foreign policy resulted in the work Polityka skandynawska Jagiellonów ('Scandinavian Policy of the Jagiellonians'). Such a comparative approach was to fascinate Polish historians in later years, for example Antoni Mączka (1928-2003), who in the 1970s and in the 1980s in many of his works conducted interesting and inspiring analyses of the systems of government by the gentry in Denmark and Commonwealth in the $16^{\text {th }}$ and $17^{\text {th }}$ centuries and of the models of nepotism functioning in both countries.

Some interesting questions arise here, for example the question about the causes of diverse evolutions of the both states and their societies, and the question of what mechanisms and phenomena allowed Denmark to transform into an absolutist state with an excellent legal and political system, whereas the Commonwealth was on the decline, falling into ruin.

Denmark and Sweden, the two Nordic countries nearest to Poland and historically the closest, also in the post-war period (until 1898), are the ones that have aroused the most interest in Polish historians. The history of both the countries have been described in synthetic works; those works, although almost half a century old and incriminated by the times they were written, are still in circulation as newer works are missing; the ones concerning Denmark were written by Władysław Czapliński (1905-1981): Dzieje Danii nowożytnej 1500-1975

5 Elementa ad fontium editiones. Res Polonicae ex Archivo Regni Daniae. Pars I collegit Leon Koczy, Pars II, II, IV, V, ediderunt Carolina Lanckorońska et Georgius Steen Jensen (Romae 1964, 1969, 1971, 1972).

6 O. Halecki, Dzieje unii jagiellońskiej (Cracow: Akademia Umiejętności, 1919-1920); O. Halecki Polityka skandynawska Jagiellonów (Warsaw: Towarzystwo Naukowe Warszawskie, 1927).

7 A. Mączak, Nobility in comparative perspective (Oslo: Universitetsforlaget, 2000); A. Mączak, Klientela. Nieformalne struktury władzy w Polsce i Europie w XVI-XVIII w. (Warsaw: Wydawnictwo Naukowe Semper, 1994/2000); A. Mączak, "Dania i Rzeczpospolita w dobie nowożytnej. Problemy i perspektywy badań porównawczych", Zapiski Historyczne, 47 (1982) 4.

8 Czapliński, Górski, Historia Danii; W. Czapliński, Dzieje Danii nowożytnej 1500-1975 (Warsaw: PWN, 1982). 
('A History of Modern-Age Denmark') and - in cooperation with Karol Górski (1903-1988) - Historia Danii ('A History of Denmark'). Historia Szwecji (‘A History of Sweden') written by Adam Kersten (1930-1983) is more modern, and it is perfectly supplemented by the work written by Ingvar Andersson A History of Sweden (translated into Polish by Adam Kersten). ${ }^{9}$ Those two syntheses have been functioning in academic circulation up to the date, although in some aspects they are anachronistic, inter alia because the authors put too much emphasis on the traditional history of events passing over the social history and culture, especially in the anthropological sense. The series was continued with Historia Finlandii ('A History of Finland') written by Tadeusz Cieślak; although it includes biased interpretations of - for example - the Winter War (1939-1940), it is still an important source of knowledge on the history of Finland..$^{10}$ Cieślak also wrote a very general synthesis of the history of the whole Nordic region of the $19^{\text {th }}$ and $20^{\text {th }}$ centuries, the one-volume Zarys historii najnowszej krajów skandynawskich. ${ }^{11}$ Tadeusz Cieślak (1917-1985) was one of the historians who in the 1970s and in the 1980s explored the history of Scandinavia and mutual relations very actively; in addition to the already mentioned syntheses he published some short collections of essays, e.g. Szwecja: z dziejów XIX i XX wieku (Poznań Publisher, 1969), Norwegia: z dziejów XIX i XX wieku (Poznań Publisher, 1970), Polska-Skandynawia w XIX i XX wieku: szkice historyczne (Poznań Publisher, $1973)^{12}$. It should be noted that Cieślak's interest in the history of Scandinavia was only a tiny part of his academic passions.

The publishing of the bulky work Tysiaclecie polsko-skandynawskich stosunków kulturalnych written by Kazimierz Ślaski (1912-1990) is a very important landmark in the history of the Polish Scandinavian historiography. ${ }^{13}$ The publication, on the one hand encyclopaedic in character, on the other a kind of synthesis, not only inspired many Polish research workers to concentrate on the Polish-Nordic contacts throughout the history, but also initiated one of the most

9 A. Kersten, Historia Szwecji (Wrocław: Ossolineum 1973); I. Andersson, Dzieje Szwecji, transl.

A. Kersten (Warsaw: PWN, 1967).

10 T. Cieślak, Historia Finlandii (Wrocław: Ossolineum 1983).

11 T. Cieślak, Zarys historii najnowszej krajów skandynawskich (Warsaw: PWN, 1978).

12 T. Cieślak, Szwecja: z dziejów XIX i XX wieku (Poznań: Wydawnictwo Poznańskie, 1969); T. Cieślak, Norwegia: z dziejów XIX i XX wieku (Poznań: Wydawnictwo Poznańskie 1970); T. Cieślak, Polska-Skandynawia w XIX i XX wieku: szkice historyczne (Poznań: Wydawnictwo Poznańskie, 1973).

${ }_{13}$ K. Śląski, Tysiąclecie polsko-skandynawskich stosunków kulturalnych (Wrocław: Ossolineum 1977). 
important topics in the Polish research into Scandinavian questions: the one of mutual relations.

Before 1989 and now the Polish research into the Nordic region has been dispersed, conducted at the Philological Faculties (e.g. in Poznań and Gdańsk), or undertaken by individual workers at the Institute of History (IH) at the Polish Academy of Sciences (PAN) and other academic centres. Talking about the research centres and workers that dealt with Scandinavian questions before 1989 and in addition to the already presented Tadeusz Cieślak (IH PAN), among the ones that deserve to be mentioned is Zdzisław Grot (1903-1984), related to the Institute of History of the Adam Mickiewicz University, although his work Pruska polityka narodowościowa w pótnocnym Szlezwiku 1864-1920 was only a subplot of his research activity; his main area of research was the history of the Grand Duchy of Posen, and it must have led him to the topic of Schleswig and Prussia. ${ }^{14}$ The history of Scandinavia, especially the history of Norway, is among the research areas of Janusz Małłek (his other areas of research being the modern history of Prussia and the Reformation in the Polish lands) from the Nicolaus Copernicus University (UMK) of Toruń, Karol Górski's disciple (Karol Górski was the one of the authors of Historia Danii). His outstanding achievements may be proved by Volume 3 of his series Opera selecta. Skandinavica. ${ }^{15}$ Professor Małłek's role in the development of the Polish Scandinavian Studies will be still discussed beneath.

In turn, Bernard Piotrowski (1939-2015) was related to the Scandinavian Institute of the Adam Mickiewicz University (UAM) in Poznan, the author of such works as Walka Norwegów o rozwiązanie unii politycznej ze Szwecją 1884-1907 ('The Struggle of the Norwegians to Dissolve their Political Union with Sweden'). ${ }^{16}$ In the case of this scholar Scandinavia was the main area of research, and among many important and revolutionary for the Polish historiography works the ones that should be mentioned deal with the process of Nordic integration, the origin of which Piotrowski saw in the Viking community: Tradycje jedności

14 Z. Grot, Pruska polityka narodowościowa w pótnocnym Szlezwiku 1864-1920 (Poznań: Wydawnictwo Poznańskie, 1967).

15 J. Małłek, Opera selecta, vol III. Skandinavica (Toruń: Wydawnictwo Naukowe UMK, 2016).

16 B. Piotrowski, Walka Norwegów o rozwiąanie unii politycznej ze Szwecja 1884-1907 (Poznań: Wydawnictwo Naukowe UAM, 1974). 
Skandynawii: od mitu wikińskiego do idei nordyckiej and Integracja Skandynawii: od Rady Nordyckiej do wspólnoty europejskiej. ${ }^{17}$

Many interesting observations may be made looking at particular academic centres. What is seen is the fact that individual research areas are consequently attributed to them, which makes the activities of Polish academic institutes in the sphere of the Scandinavian studies be marked clearly on the map of the Polish historiography of the Nordic countries. It goes without saying that the above mentioned centres are teaching centres, among other things of Scandinavian languages, which results in Master, Doctoral and Habilitation dissertations. One of the oldest institutions of that type - and the very few (sic) - is the Faculty of History of UMK in Torun, which comprises several institutes, one of them is the Institute of History and Archival Studies, which in turn comprises some basic structural units, and one of them is the Unit of the History of the Baltic Countries. In the 1960s Tadeusz Małłek, inspired by Karol Górski, began research into the history of Scandinavia. The first structural units where the modern history of the Nordic countries was investigated were created in the Torun University on the initiative of Janusz Małłek, and so were the first (Master and Doctoral) seminars. After numerous changes in its name the present Unit of the History of the Baltic Countries deals with the research areas of the Scandinavian countries of various periods. Among the people that should be mentioned here is Emilia Denkiewicz-Szczepaniak, who within the Torun University (namely, within the Institute of Scandinavian Studies and Applied Linguistics) has created an important milieu of people (Masters, doctors), who are carrying out research into the political and social history of Norway of the $20^{\text {th }}$ century. E. Denkiewicz-Szczepaniak belongs to the historians who conduct research into the history of Norway during the Second World War and into the Polish emigration to that country. Contrary to many authors who have been publishing works concerning the years 1940-1945 on the basis of Anglo-Saxon sources and literature, E. Denkiewicz-Szczepaniak refers to original sources, including the archival sources in the Norwegian archives. ${ }^{18}$ A kind of review of the academic production of the young historians from the

17 B. Piotrowski, Tradycje jedności Skandynawii: od mitu wikińskiego do idei nordyckiej (Poznań: Wydawnictwo Naukowe UAM, 2006); B. Piotrowski, Integracja Skandynawii: od Rady Nordyckiej do wspólnoty europejskiej (Poznań: Wydawnictwo Naukowe UAM, 2006).

18 E. Denkiewicz-Szczepaniak, Polska siła robocza $w$ Organizacji Todta $w$ Norwegii $i$ Finlandii $w$ latach 1941-1945 (Toruń: Wydawnictwo UMK, 1999); E. Denkiewicz-Szczepaniak, "Norwegia na drodze dylematów i przemian 1945-1949”, Roczniki Towarzystwa Naukowego w Toruniu (1992). 
milieu created by E. Denkiewicz-Szczepaniak is a collection of studies edited by her, entitled Norwegia w I polowie XX wiek $u^{19}$.

The second academic centre where an interesting milieu is in statu nascendi is the group of historians at the Gdańsk University. Gabriela Majewska, ${ }^{20}$ a research worker specialising in the modern-age history of Sweden and the Polish-Swedish relations of the same time, is related to the Faculty of History; Arnold Kłonczyński, a historian exploring the history of the $20^{\text {th }}$ century, first of all of Sweden (economy, the Polish emigration) ${ }^{21}$. At Polish universities cooperation between institutes is a rare phenomenon, but the Institute of History and the Institute of Scandinavian Studies have established it. The scope of the cooperation exceeds regular teaching and research in the philological sphere, and approaches the discipline which is called Regional Studies including culture, politics, society and history of the Nordic states. Such a programme of teaching and research has been set up by the founders of the Gdańsk Scandinavian Studies, the two outstanding scholars and experts in the history of culture of the Scandinavian countries and the mutual Polish-Nordic relations: Jan Szymański (1941-2007) and Zenon Ciesielski. Jan Szymański initiated an important trend in historical research, focusing on the Polish-Scandinavian economic relations, now continued by - inter alios Bolesław Hajduk (see beneath) and many other young scholars from Szczecin and Gdańsk $^{22}$. Among numerous publications written by Z. Ciesielski, concerning the Polish-Scandinavian cultural relations there is one that attracts a lot of attention: his opus magnum, over a thousand pages of the two-volume Dzieje kultury skandynawskiej, and the famous anthology Skandynawia woczach Polaków, often quoted and an inspiration to next generations. ${ }^{23}$ What the private library of each scholar

19 E. Denkiewicz-Szczepaniak, ed. Norwegia w I połowie XX wieku (Toruń: Wydawnictwo UMK, 2004).

20 G. Majewska, Polityka handlowa Szwecji w latach 1720-1809 (Wrocław: Ossolineum, 1991); G. Majewska, Szwecja: kraj, ludzie rządy w polskiej opinii drugiej połowy XVIII wieku (Gdańsk: Wydawnictwo UG, 2004).

21 A. Kłonczyński, Stosunki polsko-szwedzkie w latach 1945-1956 (Gdańsk: Wydawnictwo UG, 2007); A. Kłonczyński, ,My w Szwecji nie porastamy mchem...”: emigranci z Polski w Szwecji w latach 1945-1980 (Gdańsk: Wydawnictwo UG, 2012).

22 J. Szymański, Stosunki gospodarcze Polski z Norwegia w latach 1918-1929 (Gdańsk: Wydawnictwo UG, 2005); J. Szymański, Stosunki gospodarcze Polski ze Szwecja 1919-1939 (Gdańsk: Gdańskie Towarzystwo Naukowe, 1978); J. Szymański, Polsko-skandynawska wspótpraca w zakresie żeglugi w okresie międzywojennym 1919-1939 (Gdańsk: Wydawnictwo UG, 1988).

23 Z. Ciesielski, Dzieje kultury skandynawskiej, vol. 1-2 (Gdańsk: Marpress, 2016); Z. Ciesielski, introduction, selection, ed., Skandynawia w oczach Polaków (Gdańsk: Wydawnictwo Morskie, 1974). 
specialising in Scandinavian Studies, philologist or historian, cannot be missing is Stownik pisarzy skandynawskich edited by Z. Ciesielski. ${ }^{24}$

The third teaching and research centre is being created in the Institute of History and International Relations of the Szczecin University, where the Scandinavian research is coordinated by Bolesław Hajduk. The research scope includes first of all the socio-economic history of the $20^{\text {th }}$-century Scandinavia, the mutual Polish-Scandinavian commercial relations, as well as the Polish emigration to the Nordic countries. B. Hajduk has been publishing the results of his research in series of articles concerning, inter alia, the economic Polish-Scandinavian contacts, especially the Polish-Danish and the Polish-Norwegian ones. ${ }^{25}$

It is worth reminding the figure of Leszek Słupecki, working at the Rzeszów University at the Unit of Medieval History and Nordic Studies of the Faculty of Sociology and History, ${ }^{26}$ which like many other centres of this kind gathers young seminar students.

In addition to these clearly defined research centres, on the map of the Polish Scandinavian historiography there are names of individual research workers, who function in various academic milieux and in various research fields. The historians whose universities run Scandinavian studies are in a much better situation, as such universities can easily start seminars and language courses, which is the case of the Jagiellonian University, where research into the modern history of Sweden is conducted by Wojciech Krawczuk, ${ }^{27}$ or the Szczecin University and the Gdańsk University. Such cooperation is usually fruitful, especially if - e.g. in Gdańsk and in Szczecin - the studies exceed the framework of philology and are enriched with economic, legal and political questions.

On the other hand, the historians who carry out research without any basis of Scandinavian Studies are in much worse situation; modest and simple language course do not guarantee inflows of students. What comes as a surprise is the fact that the Warsaw University, the biggest Polish university, does not have any unit

24 Z. Ciesielski, ed. Stownik pisarzy skandynawskich (Warszawa: Wiedza Powszechna, 1991).

25 "Inter alia: Economic Relations Between Poland and Norway", Studia Maritima 22 (2009); "Norwegia w pierwszej połowie XX wieku", Nautologia 143 (2006); Polskie uchodźstwo niepodległościowe w Skandynawii w latach 1945-1989, in: Zakończenie II wojny światowej-polityka i dyplomacja międzynarodowa 1945-2005, ed. M. Nurek (Gdańsk: Fundacja Rozwoju UG, 2006).

26 L. Słupecki, Wyrocznie i wróżby pogańskich Skandynawów: studium do dziejów idei przeznaczenia u ludów indoeuropejskich (Warsaw: Instytut Archeologii i Etnologii PAN, 1998); L. Słupecki, Mitologia skandynawska w epoce wikingów (Cracow: Zakład Wydawniczy „Nomos”, 2003).

27 W. Krawczuk, Samuel Pufendorf and some stories of the Northern War 1655-1660 (Cracow: Jagiellonian University Press, 2014). 
dealing with Scandinavian Studies in its organisational structure (with the exception of a straightforward language course in the School of Foreign Languages). The author of the present article functions in such a space (the Institute of History).

Let us have a look at the achievements of Polish historians dealing with Scandinavian questions from the above mentioned academic centres from a different point of view: of their specialisation (some repetitions will be necessary). Which disciplines dominate? Which specialisations and periods are the most popular ones? And what are the weaknesses of the Polish Scandinavian historiography? It goes without saying that the most explored period are the Middle Ages. The Nordic Middle Ages in Polish research is first of all the one into their earliest parts, i.e. the ones of Vikings and Old Norse. L. Słupecki has already been mentioned, equally important has been the research of Jakub Morawiec from the Silesian University, who concentrates on sagas and skalds' poetry. ${ }^{28}$ Additionally, there are numerous editions of sagas and the poetic Edda launched by small and unknown publishers, which are deprived of any professional apparatus and as a result their academic value is doubtful. In any case, they prove the tremendous popularity of the Viking period in Poland. The tradition in Polish historical research initiated still in the inter-war period (Władysław Konopczyński, Adam Szelągowski) has been its concentration on the modern-age times. And whereas the older scholars and also some of the post-war period, like A. Kersten - were interested mainly in Polish-Scandinavian relations (especially the Polish-Swedish ones) from the period of 'Potop', i.e. the Polish-Swedish War of the years 1655-1660, the present-day historians concentrate mainly on the strictly Scandinavian questions. For many years Janusz Małłek has been conducting interesting research into the history of Reformation and religion, and the Polish-Nordic diplomatic and cultural relations, recently gathered in the above mentioned Opera selecta. ${ }^{29}$ Zbigniew Anusik, a historian from the Łódz University carries out research into the modern history of Sweden, and - on the one hand - explores the problems of the Swedish diplomacy in the $17^{\text {th }}-18^{\text {th }}$ centuries, and on the other he is the author of important

\footnotetext{
28 J. Morawiec, Między poezja a polityką: rozgrywki polityczne w Skandynawii XI wieku w świetle ówczesnych skaldów (Katowice: Wydawnictwo Uniwersytetu Śląskiego, 2016); J. Morawiec, Knut Wielki, król Anglii, Danii i Norwegii (ok. 955-1035) (Cracow: Wydawnictwo „Avalon”, 2013); J. Morawiec, Norwegia. Series „Początki państw” (Poznań: Wydawnictwo Poznańskie, 2017).

29 Małłek, Opera selecta.
} 
biographies of the Swedish monarchs of the Absolutist Sweden. ${ }^{30}$ The Absolutist Sweden is also the area of interest of the above mentioned historian from the Gdańsk University, Gabriela Majewska.

In addition to those traditional problems and equally traditional approach, there has appeared an interesting and completely new trend in research into the history of culture and ideas of the Nordic countries in modern times, with new research methods. The scholar that should be mentioned here is Krystyna Szelągowska from the Białystok University; her watershed works concerning the shaping of the national awareness of the Norwegians from the $17^{\text {th }}-18^{\text {th }}$ centuries were enthusiastically received in Norway. ${ }^{31} \mathrm{~K}$. Szelągowska is also the author of the biography of Ludwig Holberg, an outstanding figure of the Scandinavian Enlightenment; it was the first biography of that figure published in Poland. ${ }^{32} \mathrm{An}$ other historian concentrated on the modern-age period in Scandinavia is Maria Sibińska from the Institute of Scandinavian Studies of the Gdańsk University; she continues the trend initiated by the founders of the Institute; the trend consists in combining history with research into culture and literature; she focuses her academic interest on the history of theatre of the Enlightenment and of later epochs. ${ }^{33}$

Polish historians devote relatively a small amount of time to the $19^{\text {th }}$ century; it might be caused by the fact that there were no important relations between the Nordic countries and the Polish lands under the rule of the partitioners. Tiny collections of essays written by T. Cieślak (cf. Footnote 12) and by Z. Grot (cf. Footnote 14) have already been mentioned. In the 1980s Jadwiga Wróblewska analysed the attitude of Sweden towards the January Uprising, at the same time raising the question of the Nordic unionism, the Scandinavism. ${ }^{34}$ That question was discussed more extensively by the author of this article, where she based her

30 Z. Anusik, Dyplomacja szwedzka wobec kryzysu monarchii we Francji w latach 1787-1792 (Łódź: Wydawnictwo Uniwersytetu Łódzkiego, 2000); Z. Anusik, Gustaw II Adolf (Wrocław: Ossolineum, 1996); Z. Anusik, Karol XII (Wrocław: Ossolineum, 2006).

31 K. Szelągowska, inter alia „My Norwegowie”. Tożsamość narodowa norweskich elit w czasach nowożytnych (Cracow: Avalon, 2011) (the book available also in the English translation at: http:// repcyfr.pl/dlibra/docmetadata?id $=8222 \&$ from=publication $\&$ ).

32 K. Szelągowska, Ludvig Holberg: uczony, pisarz, prześmiewca (Białystok: Instytut Badań nad Dziedzictwem Kulturowym Europy, 2014).

33 M. Sibińska, Skandynawski wiek światel. Doświadczenia teatralne Ludviga Holberga (Gdańsk: Wydawnictwo Uniwersytetu Gdańskiego, 2011); Ludvig Holberg: na tropach wspólnej tożsamości europejskiej (Gdańsk: Fundacja Rozwoju Uniwersytetu Gdańskiego, 2005).

34 J. Wróblewska, Szwecja wobec powstania styczniowego (Wrocław: Ossolineum, 1986). 
conclusions on the archival sources and the $19^{\text {th }}$-century prints. ${ }^{35}$ The $19^{\text {th }}$ century has also been explored by Michalina Petelska, who examines the literary legacy of Georg Brandes. ${ }^{36}$ It should be expected that in the future she will not restrict herself to mutual relations, but she will try to look at the social and cultural phenomenon of Brandes in the context of the $19^{\text {th }}$-century Danish and Norwegian culture.

On the other side of the temporal axis there is an abundant literature, and for a few decades a literature devoted to the history of the Nordic region during the Second World War, with a special emphasis on the Polish episode, i.e. the battles of Narvik. And here again in addition to the academic works meeting the standards of professional academic research, there are publications that are of much worse quality. One of the first such works was the profusely documented book entitled Ruch oporu w Danii 1940-1945 written by Władysław Czapliński. ${ }^{37}$ The opposite extreme is represented by a publication with a bibliography which includes hundreds of titles, but only two in Scandinavian languages; there is not a single memoir written by a Scandinavian participant in the war, and among the archival materials there are only lists of the Polish envoys to the Nordic capitals. The author of the publication in question seems not to know the latest (I mean the works of the last 25 years!) studies concerning the Second World War, which were launched in the Nordic countries, especially in Norway. ${ }^{38}$

The modern times traditionally arouse the most interest, which is visible in the case of the above mentioned E. Denkiewicz-Szczepaniak and her disciples. The diplomacy of the war period is the area of interest of Paweł Jaworski from the Wrocław University (which will be discussed further). The scope of problems concerning that period has become much wider now, and there are prospects for Polish scholars to write innumerable works, especially concerning controversial topics, such as the question of collaboration (with the Germans during the war), the children of the Wehrmacht's soldiers, the Lebensborn action, the participation of Danish and Norwegian volunteers in the German military structures, e.g.

35 G. Szelągowska, Idea zjednoczonej Pólnocy w skandynawskim ruchu studenckim w I połowie XIX wieku (Warszawa: Wydawnictwo Uniwersytetu Warszawskiego, 1992); G. Szelągowska, Poddany $i$ obywatel. Stowarzyszenia spoleczne w Danii w dobie transformacji ustrojowej (Warsaw: Wydawnictwo DiG, 2002).

${ }^{36}$ M. Petelska, Georg Brandes i Polacy czyli o fenomenie wzajemnego zainteresowania z Polska w tle (Gdańsk: Wydawnictwo Uniwersytetu Gdańskiego, 2017).

37 W. Czapliński, Ruch oporu w Danii 1940-1945 (Wrocław: Ossolineum 1973).

38 T. Konecki, Skandynawia w Drugiej Wojnie Światowej (Warszawa: Książka i Wiedza, 2003). 
during the Warsaw Uprising. Investigating those problems from the Polish point of view would be extremely interesting.

Another research area, intensively explored, is the inter-war period, especially the Polish-Nordic bilateral relations. The economic contacts have already been discussed in the context of the specialisation of the Szczecin centre. In addition to that trend, research into the diplomatic inter-war and wartime relations has been thriving for the last fifteen or so years, especially in Wrocław. The most interesting achievements in that aspect present a work written by Paweł Jaworski, concerning the Polish-Swedish relation in the years 1939-1945, and a synthesis of the Polish-Scandinavian relations in the years 1918-1939. ${ }^{39}$ Both works deserve attention not only because of the author's approach to the topic, but also on account of a rich use of Swedish, Polish and British sources of various kinds, such as archival materials, press excerpts, memoirs, etc. The synthesis of the history of Denmark of the $20^{\text {th }}$ and $21^{\text {st }}$ centuries written by the author of the present article may be included in the historiography of the modern times, too. ${ }^{40}$

In the historiography concerning the history of Scandinavia there is still another trend, less noticeable but worth presenting: the critical edition of sources. The publications of the oldest texts - chronicles, sagas, Eddas - have a long tradition in Poland, dating back to the epoch of the Romanticism. Not all of those editions are equally valuable, but the translations produced by Apolonia Załuska-Strömberg should be mentioned; she translated the Elder (poetic) Edda and a few sagas. ${ }^{41}$ Another interesting editorial initiative was made at the Jagiellonian University, where several works, critically edited, concerning modern Scandinavia (especially Sweden) were published thanks to Wojciech Krawczuk (and in his translation), thus initiating editorial series, ${ }^{42}$ inter alia the monumental $\mathrm{Sev}$ en Books about the Deeds of Carl Gustav, the Kind of Sweden (Siedem ksiag o czynach Karola Gustawa, króla Szwecji) by Samuel Pufendorf; without that position any bibliography will be incomplete. ${ }^{43}$

39 P. Jaworski, Polska niepodległa wobec Skandynawii 1918-1939 (Wrocław: Wydawnictwo Uniwersytetu Wrocławskiego, 2001); P. Jaworski, Marzyciele i oportuniści. Stosunki polsko-szwedzkie w latach 1939-1945 (Warsaw: Wydawnictwo Uniwersytetu Wrocławskiego i IPN, 2009).

40 G. Szelągowska, Dania wXX i XXI wieku (Warsaw: Wydawnictwo TRIO, 2010).

${ }^{41}$ A. Załuska-Strömberg, transl., Saga rodu z Laxdalu (Poznań: Wydawnictwo Poznańskie, 1973); A. Załuska-Strömberg, transl., Saga o Egilu (Poznań: Wydawnictwo Poznańskie, 1974); A. Załuska-Strömberg, transl., Edda poetycka (Wrocław: Ossolineum, 1986).

42 Źródła do dziejów relacji polsko-szwedzkich Series (Cracow: Wydawnictwo Eternum).

43 S. Pufendorf, Siedem ksiąg o czynach Karola Gustawa, króla Szwecji, transl., ed. W. Krawczuk (Warsaw: Wydawnictwo DiG, 2013). 
The above reflections are just an outline of the Polish historiography concerning the history of the Nordic region. It is not difficult to notice that dominating element are the Polish-Scandinavian cultural, economic and diplomatic relations. Undoubtedly, they are important and they constitute an essential part of our knowledge about that region. Yet, the basic task of Polish historians dealing with Scandinavia is - in my opinion - to include in the Polish academic discourse the knowledge not only about the Polish-Nordic contacts, but also about the Scandinavian countries themselves and their history, as well as to popularise it. The above mentioned syntheses are half a century or so old, but they are still included in the bibliographies of the latest works; they are outdated and obsolete (there are new works, but not fully successful ${ }^{44}$ ). Undoubtedly, the impressive work by Z. Ciesielski concerning the history of the Scandinavian culture (Footnote 23) belongs to the latest achievements. It is advisable that Polish historian join in the academic discussions taking place at the Scandinavian universities on the Second World War or specific historical experiences of particular countries (e.g. Sweden during WW2, the colonial past of Denmark, the participation of Danish and Norwegian volunteers in the military structures of the Third Reich).

And the last question. In spite of many various conferences, especially the cyclic ones (Gdańsk plays an important role here), regular meetings are still missing, which might become a place to exchange ideas and experiences, but first of all a platform of integration and a meeting point for scholars from different centres, the centres of history and the ones of Scandinavian Studies.

\section{Bibliography}

Andersson I. Dzieje Szwecji, transl. A. Kersten. Warszawa: PWN, 1967.

Anusik Z. Misja polska w Sztokholmie w latach 1789-1795. Łódź: Wydawnictwo Uniwersytetu Łódzkiego, 1993.

Anusik Z. Dyplomacja szwedzka wobec kryzysu monarchii we Francji w latach 17871792. Łódź: Wydawnictwo Uniwersytetu Łódzkiego, 2000.

Anusik Z. Gustaw II Adolf. Wrocław: Ossolineum, 1996.

Anusik Z. Karol XII. Wrocław: Ossolineum, 2006.

Ciesielski Z; Introduction, selection, ed., Skandynawia w oczach Polaków. Gdańsk: Wydawnictwo Morskie, 1974.

44 B. Szordykowska, Historia Finlandii (Warsaw: Wydawnictwo TRIO, 2011); cf.: review of Ł. Sommer, Kwartalnik Historyczny 120 (2013) 3. 
Ciesielski Z; ed. Stownik pisarzy skandynawskich. Warszawa: Wiedza Powszechna, 1991. Ciesielski Z. Dzieje kultury skandynawskiej, vol. 1-2. Gdańsk: Marpress, 2016.

Cieślak T. Szwecja: z dziejów XIX i XX wieku. Poznań: Wydawnictwo Poznańskie, 1969.

Cieślak T. Norwegia: z dziejów XIX i XX wieku. Poznań: Wydawnictwo Poznańskie, 1970.

Cieślak T. Polska-Skandynawia w XIX i XX wieku: szkice historyczne. Poznań: Wydawnictwo Poznańskie, 1973.

Cieślak T. Zarys historii najnowszej krajów skandynawskich. Warsaw: PWN, 1978.

Cieślak T. Historia Finlandii. Wrocław: Ossolineum, 1983.

Czapliński W., K. Górski. Historia Danii. Wrocław-Warsaw-Cracow: Ossolineum, 1965.

Czapliński W. Ruch oporu w Danii 1940-1945. Wrocław: Ossolineum, 1973.

Denkiewicz-Szczepaniak E. Polska sita robocza w Organizacji Todta w Norwegii i Finlandii w latach 1941-1945. Torun: Wydawnictwo UMK, 1999.

Denkiewicz-Szczepaniak E. "Norwegia na drodze dylematów i przemian 1945-1949", Roczniki Towarzystwa Naukowego w Toruniu (1992).

Denkiewicz-Szczepaniak E. ed. Norwegia w I połowie XX wieku. Toruń: Wydawnictwo UMK, 2004.

Elementa ad fontium editiones. Res Polonicae ex Archivo Regni Daniae. Pars I collegit Leon Koczy, Pars II, II, IV, V, ediderunt C. Lanckorońska, G.S. Jensen. Romae 1964, 1969, 1971, 1972.

Grot Z. Pruska polityka narodowościowa w pótnocnym Szlezwiku 1864-1920. Poznań: Wydawnictwo Poznańskie, 1967.

Hajduk B. "Norwegia w pierwszej połowie XX wieku”. Nautologia 143 (2006).

Hajduk B. Polskie uchodźstwo niepodlegtościowe w Skandynawii w latach 1945-1989. In: Zakończenie II wojny światowej - polityka i dyplomacja międzynarodowa 1945-2005, ed. M. Nurek. Gdańsk: Fundacja Rozwoju UG, 2006.

Hajduk B. "Economic Relations Between Poland and Norway". Studia Maritima 22 (2009).

Halecki O. Dzieje unii jagiellońskiej. Cracow: Akademia Umiejętności, 1919-1920.

Halecki O. Polityka skandynawska Jagiellonów. Warsaw: Towarzystwo Naukowe Warszawskie, 1927.

Janion M. "Estetyka Średniowiecznej Północy". In: Problemy polskiego romantyzmu. Series III, ed. M. Żmigrodzka. Wrocław: Ossolineum 1981.

Jaworski P. Polska niepodległa wobec Skandynawii 1918-1939. Wrocław: Wydawnictwo Uniwersytetu Wrocławskiego, 2001. 
Jaworski P. Marzyciele i oportuniści. Stosunki polsko-szwedzkie w latach 1939-1945. Warszawa: Wydawnictwo Uniwersytetu Wrocławskiego, IPN, 2009.

Kersten A. Historia Szwecji. Wrocław: Ossolineum, 1973.

Kłonczyński A. Stosunki polsko-szwedzkie w latach 1945-1956. Gdańsk: Wydawnictwo UG, 2007.

Kłonczyński A. „My w Szwecji nie porastamy mchem...”: emigranci z Polski w Szwecji w latach 1945-1980. Gdańsk: Wydawnictwo UG, 2012.

Konecki T. Skandynawia w Drugiej Wojnie Światowej. Warszawa: Książka i Wiedza, 2003.

Konopczyński W. Polska a Szwecja; od pokoju oliwskiego do upadku Rzeczypospolitej 1660-1795. Toruń: Instytut Bałtycki, 1935.

Konopczyński W. Konfederacja Barska, vol. 1-2. Warszawa: Wydawnictwo Kasy im. Mianowskiego - Instytut Popierania Nauki, 1936-1938.

Konopczyński W. Kwestia battycka do XX wieku. Gdańska: Baltic Institute, 1947.

Konopczyński W. Pierwszy rozbiór Polski. Cracow: Arcana, 2010.

Krawczuk W., ed., transl. S. Pufendorf. Siedem ksiag o czynach Karola Gustawa, króla Szwecji. Warsaw: Wydawnictwo DiG, 2013.

Krawczuk W. ed., transl. Samuel Pufendorf and some stories of the Northern War 16551660. Cracow: Jagiellonian University Press, 2014.

Majewska G. Polityka handlowa Szwecji w latach 1720-1809. Wrocław: Ossolineum, 1991.

Majewska G. Szwecja: kraj, ludzie rządy w polskiej opinii drugiej połowy XVIII wieku. Gdańsk: Wydawnictwo UG, 2004.

Małłek J. Opera selecta, vol III. Skandinavica. Toruń: Wydawnictwo Naukowe UMK, 2016.

Mączak A. "Dania i Rzeczpospolita w dobie nowożytnej. Problemy i perspektywy badań porównawczych”. Zapiski Historyczne 47 (1982) 4.

Mączak A. Nobility in comparative perspective. Oslo: Universitetsforlaget, 2000.

Mączak A. Klientela. Nieformalne struktury władzy w Polsce i Europie w XVI-XVIII w. Warsaw: Wydawnictwo Naukowe Semper, 1994/2000.

Morawiec J. Knut Wielki, król Anglii, Danii i Norwegii (ok. 955-1035). Cracow: Wydawnictwo „Avalon”, 2013.

Morawiec J., Między poezja a polityką: rozgrywki polityczne w Skandynawii XI wieku w świetle ówczesnych skaldów. Katowice: Wydawnictwo Uniwersytetu Śląskiego, 2016. 
Morawiec J. Norwegia. Series „Początki państw”. Poznań: Wydawnictwo Poznańskie, 2017.

Petelska M. Georg Brandes i Polacy czyli o fenomenie wzajemnego zainteresowania z Polska w tle. Gdańsk: Wydawnictwo Uniwersytetu Gdańskiego, 2017.

Piotrowski B. Walka Norwegów o rozwiązanie unii politycznej ze Szwecją 1884-1907. Poznań: Wydawnictwo Naukowe UAM, 1974.

Piotrowski B. Tradycje jedności Skandynawii: od mitu wikińskiego do idei nordyckiej. Poznań: Wydawnictwo Naukowe UAM, 2006.

Piotrowski B. Integracja Skandynawii: od Rady Nordyckiej do wspólnoty europejskiej. Poznań: Wydawnictwo Naukowe UAM, 2006.

Sibińska M. Ludvig Holberg: na tropach wspólnej tożsamości europejskiej. Gdańsk: Fundacja Rozwoju Uniwersytetu Gdańskiego, 2005.

Sibińska M. Skandynawski wiek światet. Doświadczenia teatralne Ludviga Holberga. Gdańsk: Wydawnictwo Uniwersytetu Gdańskiego, 2011.

Słupecki L. Wyrocznie i wróżby pogańskich Skandynawów: studium do dziejów idei przeznaczenia u ludów indoeuropejskich. Warszawa: Instytut Archeologii i Etnologii PAN, 1998.

Słupecki L. Mitologia skandynawska w epoce wikingów. Cracow: Zakład Wydawniczy „Nomos”, 2003.

Szelągowska G. Idea zjednoczonej Północy w skandynawskim ruchu studenckim w I potowie XIX wieku. Warszawa: Wydawnictwo Uniwersytetu Warszawskiego, 1992.

Szelągowska G. Poddany i obywatel. Stowarzyszenia społeczne $w$ Danii $w$ dobie transformacji ustrojowej. Warszawa: Wydawnictwo DiG, 2002.

Szelągowska G. Dania w XX i XXI wieku. Warszawa: Wydawnictwo TRIO, 2010.

Szelągowska K. My Norwegowie”. Tożsamość narodowa norweskich elit w czasach nowożytnych. Cracow: Avalon, 2011 (the book also available in English translation at: http://repcyfr.pl/dlibra/docmetadata?id=8222\&from=publication $\&$ ).

Szelągowska K. Ludvig Holberg: uczony, pisarz, prześmiewca. Białystok: Instytut Badań nad Dziedzictwem Kulturowym Europy, 2014.

Szordykowska B. Historia Finlandii. Warsaw: Wydawnictwo TRIO, 2011.

Sommer Ł. Kwartalnik Historyczny 120 (2013) 3.

Szymański J. Stosunki gospodarcze Polski ze Szwecją 1919-1939. Gdańsk: Gdańskie Towarzystwo Naukowe, 1978.

Szymański J. Polsko-skandynawska współpraca w zakresie żeglugi w okresie międzywojennym 1919-1939. Gdańsk: Wydawnictwo UG, 1988. 
Szymański J. Stosunki gospodarcze Polski z Norwegia w latach 1918-1929. Gdańsk: Wydawnictwo UG, 2005.

Ślaski K. Tysiąclecie polsko-skandynawskich stosunków kulturalnych. Wrocław: Ossolineum, 1977.

Wróblewska J. Szwecja wobec powstania styczniowego. Wrocław: Ossolineum, 1986.

Załuska-Strömberg A. transl. Saga rodu z Laxdalu. Poznań: Wydawnictwo Poznańskie, 1973.

Załuska-Strömberg A. transl. Saga o Egilu. Poznań: Wydawnictwo Poznańskie, 1974

Załuska-Strömberg A. transl. Edda poetycka. Wrocław: Ossolineum, 1986.

Źródła do dziejów relacji polsko-szwedzkich (editorial series) Cracow: Wydawnictwo Eternum.

\title{
DZIEJE SKANDYNAWII W POLSKIEJ HISTORIOGRAFII WSPÓŁCZESNEJ - UWAGI I REFLEKSJE
}

Słowa kluczowe: dzieje Skandynawii w Polsce, skandynawiści polscy, historycy polscy

\begin{abstract}
Abstrakt
W artykule przedstawiono w ogólnym zarysie historyczne dokonania polskiej historiografii dziejów regionu nordyckiego - począwszy od okresu międzywojennego po czasy współczesne. Powyższa problematyka mieści się w dwóch głównych nurtach polskich historycznych badań skandynawistycznych - podejmowania tematów wskazujących na polsko-nordyckie relacje we wszelkich zakresach, oraz skupianie się na dziejach Skandynawii i regionu nordyckiego. Trzecim nurtem, najsłabiej zaznaczonym, jest w sposób nowoczesny ujęta komparatystyka w odniesieniu do historii społecznej, dziejów państw i kultury. W minimalnym zakresie występuje w polskiej historiografii edycja źródeł do dziejów regionu nordyckiego. Artykuł stanowi jednocześnie przegląd aktywności głównych ośrodków badań skandynawistycznych w Polsce, zarówno pojedynczych badaczy-historyków funkcjonujących samodzielnie w poszczególnych uniwersytetach i wydziałach historycznych, jak i centrów polskiej skandynawistyki, zwłaszcza takich, które obejmują swymi badaniami studia nad całym regionem w ujęciu interdyscyplinarnym: nad językiem, literaturą, kulturą, polityką, gospodarką i historią. W artykule zwraca się także uwagę na słabości polskich badań nad dziejami regionu nordyckiego, co wynika przede wszystkim z wielu uwarunkowań, a także z niemożności wykorzystania oryginalnych zasobów archiwalnych i źródłowych.
\end{abstract}

